\title{
New species of Temnocephala (Platyhelminthes, Temnocephalida) ectosymbiont on vulnerable species of aeglids (Crustacea, Anomura) from the Neotropical Region
}

\author{
Samantha Alves Seixas ${ }^{1 *}$, Norton Dametto ${ }^{2}$ \& Eduardo Périco ${ }^{1}$ (i) \\ ${ }^{1}$ Universidade do Vale do Taquari - Univates, Programa de Pós Graduação Ambiente e Desenvolvimento, \\ Av. Avelino Talini 171, 95914-014, Lajeado, RS, Brasil \\ ${ }^{2}$ Universidade do Vale do Taquari - Univates, Laboratório de Ecologia e Evolução \\ Lajeado, RS, Brasil \\ *Corresponding author: Samantha Alves Seixas, e-mail: samantha_bio@yahoo.com.br
}

SEIXAS, S.A., DAMETTO, N., PÉRICO, E. New species of Temnocephala (Platyhelminthes, Temnocephalida) ectosymbiont on vulnerable species of aeglids (Crustacea, Anomura) from the Neotropical Region. Biota Neotropica. 18(4): e201704725. http://dx.doi.org/10.1590/1676-0611-BN-2017-0475

\begin{abstract}
A new species of the genus Temnocephala Blanchard, 1849 from southern Brazil was found on two species of anomuran crustaceans, Aegla spinipalma Bond-Buckup \& Buckup, 1994 and Aegla grisella Bond-Buckup \& Buckup, 1994, the latter classified as a vulnerable species by the "Lista de Referência da Fauna Ameaçada de Extinção no Rio Grande do Sul. Decreto no 41.672, de 11 junho de 2002”. The crustaceans were collected from a tributary creek of the Forqueta river, Perau de Janeiro, Arvorezinha and a tributary creek of the Fão river, Pouso Novo, Rio Grande do Sul, Brazil; both localities belong to the Sub-Basin of Forqueta River. The new species differs from seven other temnocephalans epibionts on Aegla Leach, 1820, by having the following characters: 1. a long and slightly curved cirrus, 2 . two vaginal sphincters, one proximal, big and asymmetric, and one distal, smaller and symmetric, and; 3. longer than wide, elongated epidermal 'excretory' syncytial plates (EPs), with a almost horizontally central excretory pore, displaced to the anterior portion of the plate. The new species' EP is the largest in total length among epibionts temnocephalans in crustaceans already registered. Regarding the similarities with the male reproductive system of Temnocephala axenos Monticelli, 1898, the new species has important differences in the female reproductive system. It has a larger proximal vaginal sphincter, located in the middle of the vagina, while the smaller distal one is at the extreme end of the organ. Besides that, the vaginal portion between the proximal and distal sphincters is conspicuous, with a strong muscular wall. This is the first record of a species of Temnocephala in the Taquari Valley, as well in the 'Perau de Janeiro', which is an area with a rich endemic fauna. Keywords: crustacean, ectosymbiont, South America, symbiosis, Taxonomy.
\end{abstract}

\section{Nova espécie de Temnocephala (Platyhelminthes, Temnocephalida) ectosimbionte sobre espécies vulneráveis de eglídeos (Crustacea, Anomura) da Região Neotropical}

Resumo: Uma nova espécie do gênero Temnocephala Blanchard, 1849 da região sul do Brasil foi encontrada sobre duas espécies de crustáceos anomuros, Aegla spinipalma Bond-Buckup \& Buckup, 1994 e Aegla grisella Bond-Buckup \& Buckup, 1994, a última classificada como uma espécie vulnerável pela Lista de Referência da Fauna Ameaçada de Extinção no Rio Grande do Sul. Decreto no 41.672, de 11 junho de 2002. Os crustáceos foram coletados em um arroio tributário do Rio Forqueta, Perau de Janeiro, Arvorezinha e em um arroio tributário do Rio Fão, Pouso Novo, Rio Grande do Sul, Brazil; ambas localidades pertencem a Sub-Bacia do Rio Forqueta. A nova espécie se diferencia dos outros sete temnocefalídeos epibiontes sobre Aegla Leach, 1820 pelos caracteres a seguir: 1. cirro longo e levemente curvo, 2. dois esfíncteres vaginais, um proximal, grande e assimétrico e um distal, menor e simétrico, e, 3. placas sinciciais epidérmicas 'excretoras' (PEs) alongadas, mais longas do que largas, com poro excretor quase central horizontalmente e deslocado para a porção anterior da placa. A PE da nova espécie é a maior em comprimento total entre os temnocefalídeos epibiontes sobre crustáceos registrados até o momento. Embora haja similaridades com o sistema reprodutor masculino de Temnocephala axenos Monticelli, 1898, a nova espécie apresenta diferenças importantes no sistema reprodutor feminino. O esfíncter vaginal proximal é maior, localizado no meio da vagina, enquanto o distal é menor e se localiza no final do órgão. Além disso, a porção da vagina entre os esfíncters proximal e distal é conspícua, com uma forte parede muscular. Esta é a primeira espécie de Temnocephala registrada para o Vale do Taquari, assim como para o Perau de Janeiro, área com uma fauna endêmica rica.

Palavras-chave: América do Sul, crustáceos, ectosimbionte, simbiose, Taxonomia. 


\section{Introduction}

The first host taxon of temnocephalans was recorded on Crustacea Brünnich, 1772. This group also has the largest number of epibiont species of the genus Temnocephala Blanchard, 1849. From the 21 ectosymbiont species on crustaceans, seven were recorded from the species of the genus Aegla Leach, 1820: Temnocephala chilensis (Moquin-Tandon, 1846), Temnocephala axenos Monticelli, 1898, Temnocephala mexicana Vayssière, 1898, Temnocephala talicei Dioni, 1967, Temnocephala cyanoglandula Amato, Amato \& Daudt, 2003, Temnocephala mertoni Volonterio, 2007, and Temnocephala dionii Ponce de León, Berón Vera \& Volonterio, 2015.

Temnocephala chilensis was the first species of the genus to be described and was recorded consistently after that (Dioni 1967a, Damborenea 1992). However, the authors have not updated the species description using more recent techniques.

Dioni (1972) recorded T. mexicana in Aegla sp. and Parastacus sp. from Argentina. The species was described by Vayssière (1898) and redescribed by Lamothe-Argumedo (1968). Both publications were based on specimens collected from Procambarus digueti (Bouvier, 1897) and Pseudothelphusa jouyi Rathbun, 1893 (added by Lamothe-Argumedo in 1968) from Mexico.

Temnocephala talicei has also been recorded a few times (Dioni 1968, Damborenea 1992, et al. 1997), being subsequently re-described and having a neotype designated by Volonterio (2009).

Temnocephala axenos is the most well-studied species (Baer 1931, Dioni 1967b, 1968, Damborenea 1992, et al. 1997), but it has substantial taxonomic problems, such as a misidentification of the host type (Amato et al. 2003) and the loss of the holotype at the Berlin Natural History Museum because of war damage. The superficial description of $T$. axenos (Monticelli 1898) lead to the consideration of this species as a senior synonym of Temnocephala brasiliensis Merton, 1922 by Baer (1931) and Temnocephala bresslaui Pérez-González, 1949 by Dioni (1967c). Volonterio (2007) stated that T. bresslaui was erroneously synonymized by Dioni (1967c) and it is, probably, still a valid species. The author re-described T. axenos, solving some of these issues. The incomplete description of T. cyanoglandula, with only data of the male reproductive system, has led Volonterio (2007) to suggest a synonymy for this species with T. axenos or T. bresslaui. However, a recent study of the female reproductive system (Seixas et al. 2015a) has confirmed T. cyanoglandula as a valid species.

While describing T. mertoni, an epibiont species on anomuran crabs, Volonterio (2007) pointed out the difficulties of distinguishing temnocephalans species on crustaceans given the similarities in the males' reproductive system. Among other features, the author highlighted the importance of describing in detail the female reproductive system of ectosymbionts hosted by crustaceans.

Temnocephala dionii was the last species described as an ectosymbiont on Aegla neuquensis Schmitt, 1942 from Argentina (Ponce de León et al. 2015).

There are no records of temnocephalans at the Forqueta River Sub-Basin (Fig. 1), where the crustaceans fauna is less well investigated. The Forqueta and Fão Rivers, localized at the municipalities of Arvorezinha and Pouso Novo, respectively, represent the two main rivers of the sub-basin. The present study aims to describe a new species of Temnocephala ectosymbiont on Aegla spinipalma Bond-Buckup \& Buckup, 1994 and Aegla grisella Bond-Buckup \& Buckup, 1994
(Fig. 2a), which is classified as a vulnerable species by Rio Grande do Sul State Law (Marques et al. 2002). Both are being registered as new host species for neotropical temnocephalans.

\section{Material and Methods}

One hundred and six specimens of $A$. grisella were collected from a tributary creek of the Forqueta river (28 $8^{\circ} 51^{\prime} 9.85^{\prime \prime}$ ' $; 52^{\circ} 17^{\prime} 55.02^{\prime \prime} \mathrm{W}$ ), Perau de Janeiro, Arvorezinha, Rio Grande do Sul, Brazil; and eighty-two specimens of $A$. spinipalma were collected from a tributary

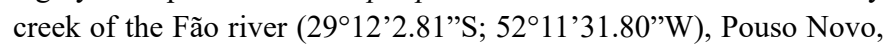
Rio Grande do Sul, Brazil. Both localities belong to Forqueta River Sub-Basin.

The collections occurred monthly between August 2014 and April 2015 as part of a larger project for taxonomic and ecological studies. All crustaceans were collected with dip nets, sexed, measured, and returned to their natural habitat. Only a few specimens $(\cong 10)$ were taken alive to the "Setor de Evolução e Ecologia, Univates" to be examined for temnocephalans.

The temnocephalans were studied through a series of techniques focusing especially on the morphology of the vagina and other female reproductive organs, as well as the morphology of the cirrus structure and the epidermal 'excretory' syncytial plates (EPs).

For general measurements, the helminths were fixed with AFA, under slight cover slip pressure, following the protocols established by Amato et al. (2007) and Seixas et al. (2010). The specimens were stained with Delafield's hematoxylin or aceto-carmine/fast green, cleared in cedar oil, and mounted as permanent slides on Canada balsam.

For the EPs studies, the specimens were dehydrated according to a protocol adapted from Kashi et al. (2014) for Scanning Electron Microscopy (SEM). The SEM preparations and photomicrographs were made at the 'Laboratório MEV (Microscopia Eletrônica de Varredura)' at Tecnovates, Univates. The images of the EPs were measured, according to Seixas et al. (2015b), using the AxioVision Zeiss LE 4.7.2 software.

Cirrus measurements were taken from extracted cirri mounted on Faure's mounting medium $(\mathrm{F})$. The terminology used to describe the male reproductive structures followed Seixas et al. (2010).

Photomicrographs of the temnocephalans were taken with the microscope Zeiss Axiolab. The line drawings and photographic images were prepared using Adobe's Fireworks ${ }^{\circledR}$ CS6 and Adobe's Photoshop ${ }^{\circledR}$ CC 2017. Measurements are in micrometers $(\mu \mathrm{m})$ unless otherwise indicated, ranges are followed (between parentheses) by the mean, the standard deviation values, and the number of specimens measured for a given character (when different than 25). The ecological concepts applied to the symbiotic organisms follow Bush et al. (1997).

The whole mounts of adult and juvenile specimens, as well as slides containing individual cirri mounted on $\mathrm{F}$ were deposited in the following scientific collections: 1. 'Coleção Helmintológica do Instituto Oswaldo Cruz (CHIOC)', Rio de Janeiro, RJ, Brazil; 2. 'Colección de Invertebrados, División Zoología Invertebrados, Museo de La Plata (MLP)', La Plata, Argentina; and 3. 'Coleção de Invertebrados do Instituto Nacional de Pesquisas da Amazônia (INPA)', Manaus, AM, Brazil. Some host specimens were deposited in the 'Coleção de Crustáceos, Departamento de Zoologia, UFRGS', Porto Alegre, RS, Brazil, and 'Coleção Zoológica, Museu de Ciências Naturais da Univates (MCN/UNIVATES)', Lajeado, RS, Brazil. The remaining 
New species of Temnocephala on aeglids
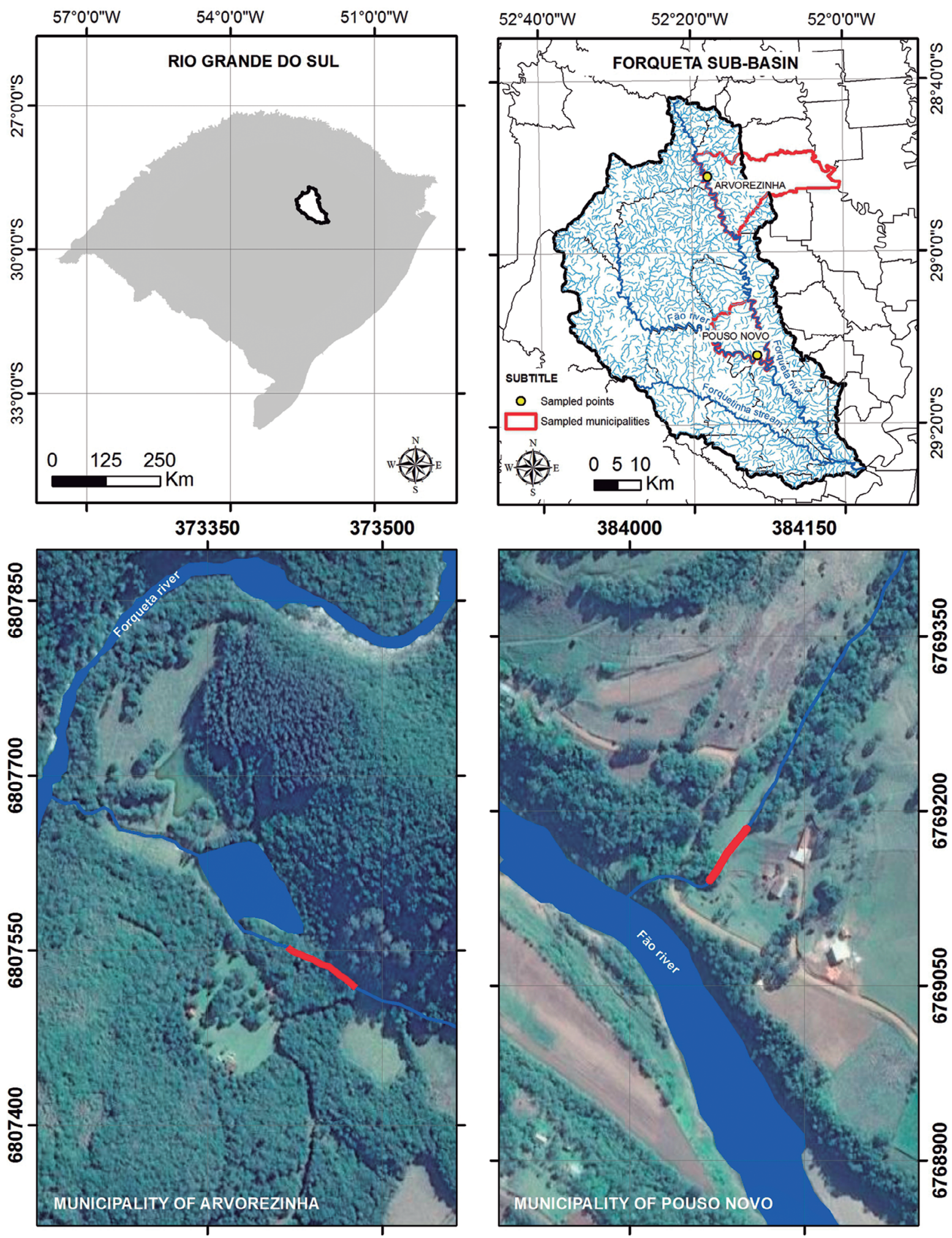

\section{SUBTITLE}
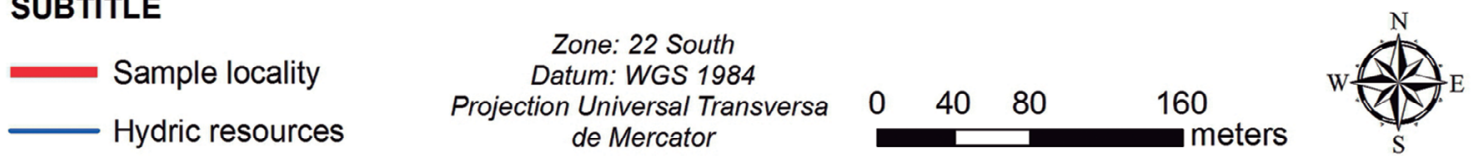

Figure 1. Map of Rio Grande do Sul showing the Forqueta River Sub-Basin and collection points in the municipalities of Arvorezinha and Pouso Novo. 
Seixas, S.A. et al.
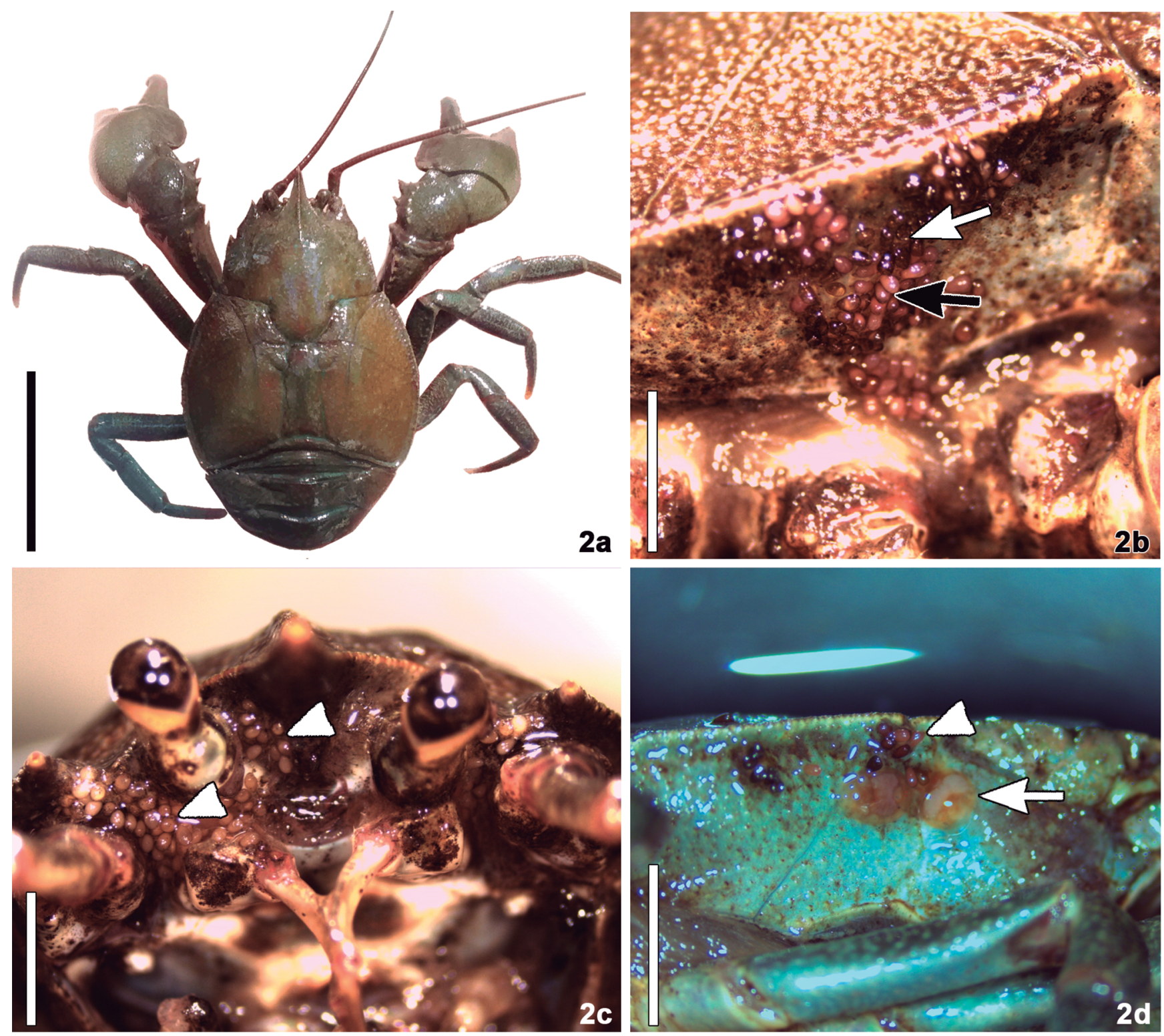

Figure 2. (2a) Aegla grisella. Scale bar $=20 \mathrm{~mm}$. (2b) Pleural side of carapace showing unhatched eggs (black arrow) and hatched eggs (white arrow) of Temnocephala grisella sp. nov. Scale bar $=5 \mathrm{~mm}$. (2c) Eggs of Temnocephala grisella sp. nov. deposited in the orbital cavity and mouthparts (head arrows). Scale bar $=2 \mathrm{~mm}$. (2d) Pleural side of carapace showing unhatched eggs (head arrow) and live specimens of Temnocephala grisella sp. nov. (arrow). Scale bar $=5 \mathrm{~mm}$.

specimens are kept in the laboratory for completion of the other studies. All material will be deposited at the 'Coleção Zoológica, Museu de Ciências Naturais da Univates (MCN/UNIVATES)’ upon conclusion of these studies.

\section{Results}

Description. Based on 63 temnocephalans specimens collected from A. grisella and 34 specimens from A. spinipalma: 13 whole mounted adults from $A$. grisella, 12 whole mounted adults from $A$. spinipalma, 3 dissected cirri from $A$. grisella, and 2 dissected cirri from $A$. spinipalma measured.

External characteristics. Body (without tentacles) (Figs 3a and 8d) $1.42-4.05 \mathrm{~mm}(2.65 \mathrm{~mm} \pm 700)$ long, $1.05-2.39 \mathrm{~mm}(1.69 \mathrm{~mm} \pm 360)$ wide; adhesive disk ventral, subterminal, partially covered by the body (Fig. 3a) 276-790 (502 \pm 116$)$ long, 434-889 (597 \pm 127$)$ wide; disc peduncle 217-632 $(424 \pm 111)$ wide. Eyespots with red pigmentation (observations made on live specimens). Two EPs longer than wide (Figs 5 and 6) 347.5-447.5 (397.5 \pm 58 ; 4) total length, 110-132.5 (121 \pm 13 ; 4) total width; length of the anterior portion of the EP from the excretory pore 117-158 (138 $\pm 24 ; 4)$, length of the posterior portion of the EP from the excretory pore $230-289(260 \pm 34 ; 4)$; width of the external limit of the EP from the excretory pore $62-69(65 \pm 4 ; 4)$; width of the internal limit of the EP from the excretory pore $49-64(56 \pm 9 ; 4)$. The excretory pore is almost central horizontally, but displaced to the anterior portion of the plate. Seventeen percent of the total length of the EP is beyond the limit of the tentacles with the body. Ratio of total length of the EPs/total body length (without tentacles): 6.7: 1 . 
New species of Temnocephala on aeglids
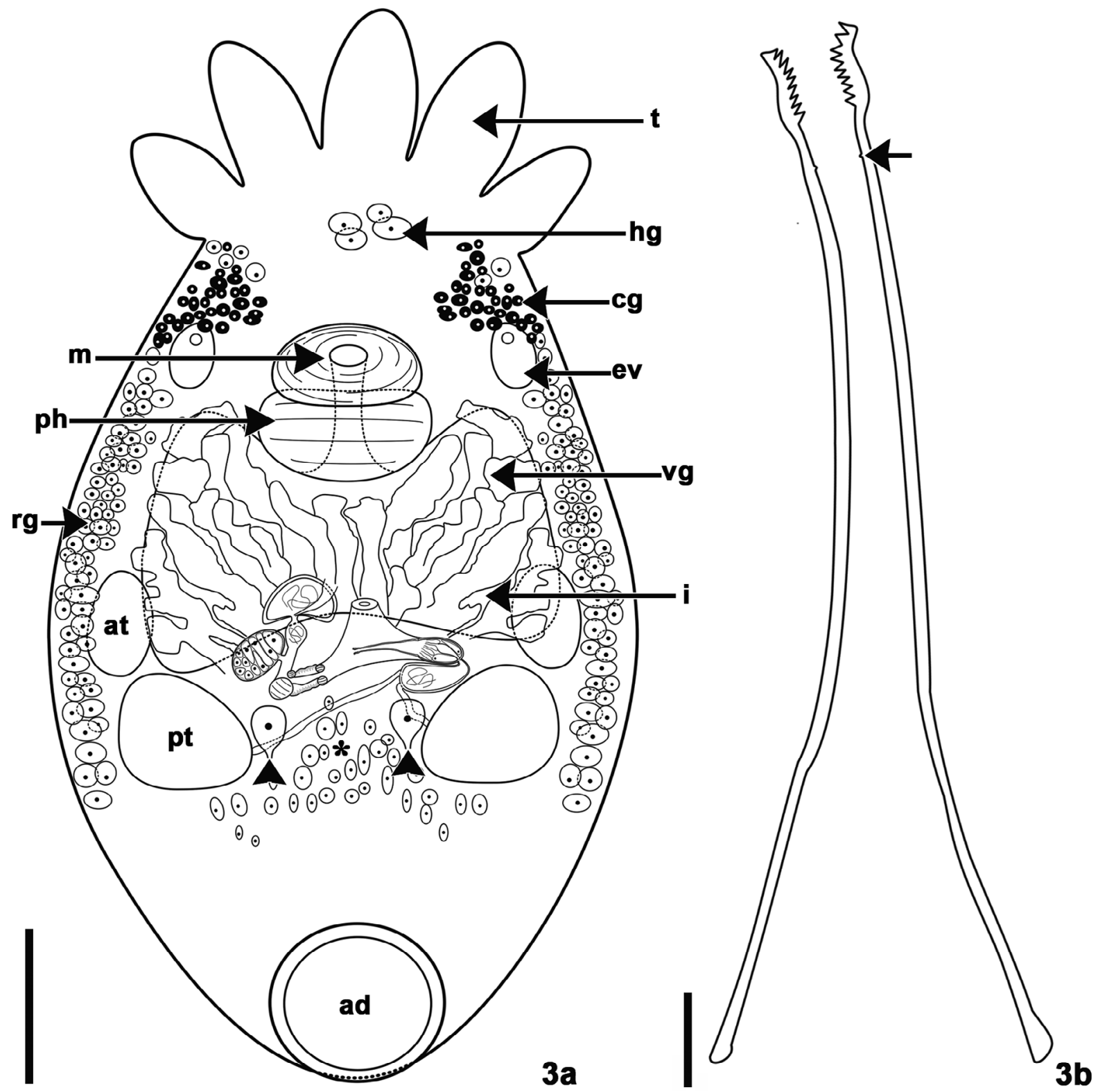

Figure 3. Temnocephala grisella sp. nov. (3a) Diagram of an adult specimen showing adhesive disk (ad), disc glands (asterisks), anterior testes (at), cyanophilous glands (cg), excretory vesicle (ev), paranephrocytes (head arrows), Haswell glands (hg), intestine (i), mouth (m), pharynx $(\mathrm{ph})$, posterior testis $(\mathrm{pt})$, rhabditogenic glands $(\mathrm{rg})$, tentacles $(\mathrm{t})$, and vitelline glands $(\mathrm{vg})$. Scale bar $=500 \mu \mathrm{m}$. (3b) Cirrus, showing the proximal limit of the introvert (arrow). Scale bar $=20 \mu \mathrm{m}$.

Glands. Rhabditogenic glands (Figs 3a and 8d) forming bunches (average 92 cells) extending from the level of the Haswell glands to the end of the posterior testes, in lateral fields of the body, 30-90 (67 \pm 15$)$ in diameter, ducts inconspicuous. Grape-like bunches of cyanophilous glands (Figs 3a and 8d) (average 20 cells), located at the level of the excretory vesicles. Two groups of two Haswell glands (Fig. 3a), showing little affinity with hematoxylin/aceto-carmine/fast green, in front of the cerebral transverse band; diameter of largest cell 65-160 (107 \pm 30$)$. Disc glands between adhesive disc and genital complex, 30-80 (52 \pm 16 ; 24) in diameter, including two pairs of large, round, more central paranephrocytes, 52.5-160 (107 $\pm 32 ; 24)$ long (Fig. 3a).
Reproductive system. Female. Vitellarium arborescent and thin (Fig. 3a); vagina elongated 65-137 $(99 \pm 23 ; 10)$ total length (Figs 4a, $8 b-8 c$ ); divided into two portions, before (BPS) and after (APS) the proximal sphincter. BPS portion 40-87 (60 \pm 15 ; 9) long, 37-75 (48 \pm 11 ; 9) wide, with thin wall (Figs $4 \mathrm{a}$ and $8 \mathrm{~b}$ ); APS portion 25-52 (38 \pm 9 ; 13) long, 40-75 $(57 \pm 10 ; 13)$ wide, with strong muscular wall (Figs 4a, 8a - 8b). Ovary 97-242 (145 $\pm 29 ; 23)$ long, 82-172 (113 \pm $25 ; 23)$ wide, located in the middle of the BPS portion of the vagina (Figs 4a, 8a-8c). Proximal vaginal sphincter asymmetrical 62-105 $(83 \pm 13 ; 16)$ total diameter (Figs $4 \mathrm{a}, 8 \mathrm{a}$ and $8 \mathrm{c}$ ), diameter of anterior portion $15-27(24 \pm 4 ; 14)$ (Figs $4 \mathrm{a}$ and $8 \mathrm{~b}$ - apvs), diameter of posterior 


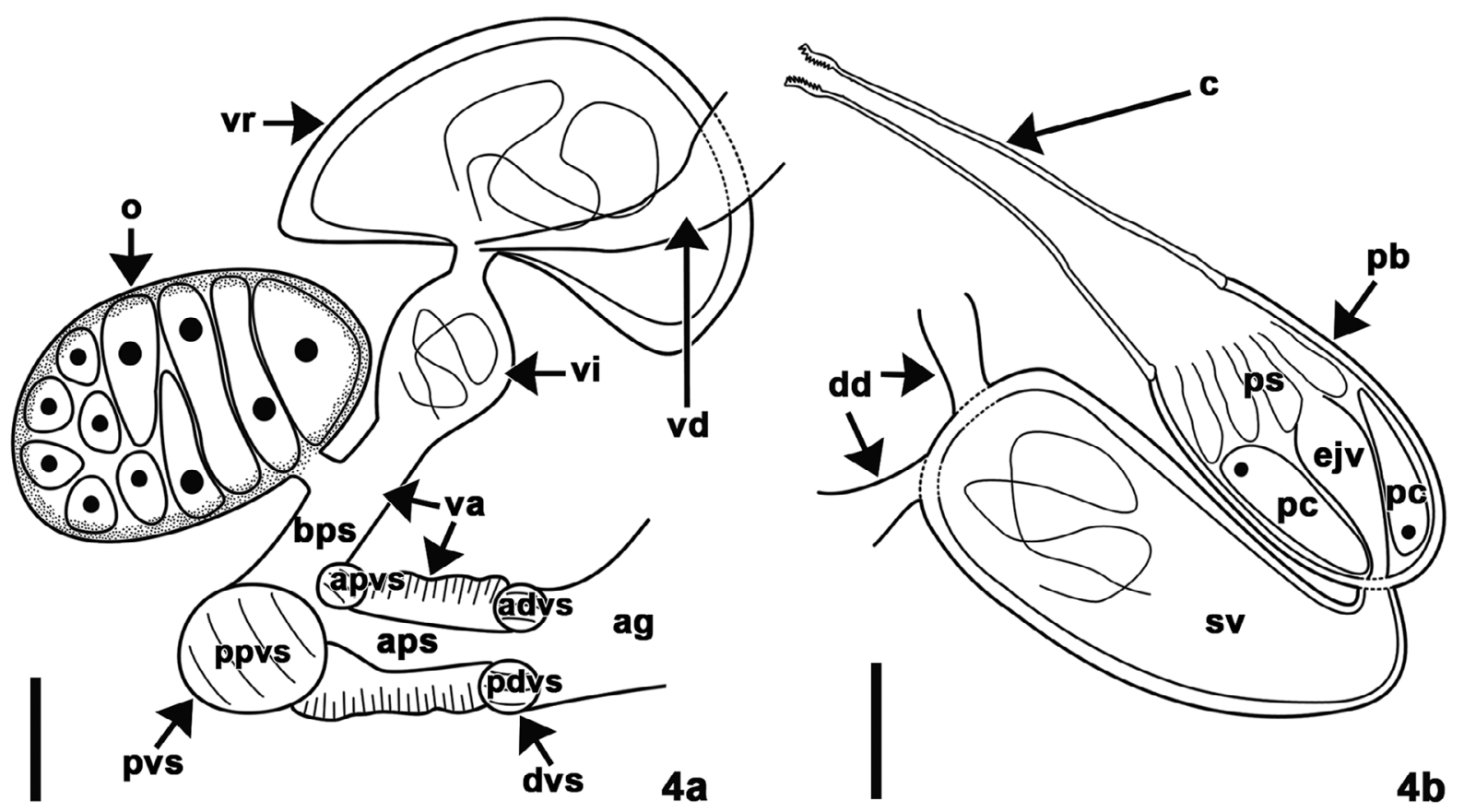

Figure 4. Temnocephala grisella sp. nov. (4a) Female reproductive system, showing: Anterior portion of the distal vaginal sphincter (advs), after proximal sphincter of the vagina (aps), anterior portion of the proximal vaginal sphincter (apvs), before proximal sphincter of the vagina (bps), distal vaginal sphincter (dvs), genital atrium (ga), ovary (o), posterior portion of the distal vaginal sphincter (pdvs), posterior portion of the proximal vaginal sphincter (ppvs), proximal vaginal sphincter (pvs), vagina (va), vitelline duct (vd), vesicula intermedia (vi), and vesicula resorbens (vr). Scale bars $=100 \mu \mathrm{m}$. (4b) Male reproductive system, showing: Cirrus (c), deferent vessels (dd), ejaculatory vesicle (ejv), prostatic bulb (pb), prostatic cells (pc), prostatic secretions (ps), and seminal vesicle (sv). Scale bars $=100 \mu \mathrm{m}$.

portion $27-65(45 \pm 14 ; 14)$ (Figs $4 \mathrm{a}$ and $8 \mathrm{~b}$ - ppvs); distal vaginal sphincter symmetrical $40-85(56 \pm 13 ; 16)$ total diameter (Figs $4 a$, $8 \mathrm{a}-8 \mathrm{~b})$, diameter of anterior portion 15-37 (24 \pm 6 ; 16) (Figs $4 \mathrm{a}$ and $8 \mathrm{c}-\mathrm{advs}$ ), diameter of posterior portion 15-37 (25 \pm 7 ; 16) (Figs 4a and $8 \mathrm{c}-$ pdvs). Vesicula intermedia $35-100(66 \pm 21 ; 11)$ long (Figs $4 \mathrm{a}$ and 8a); vesicula resorbens usually full of sperm, 60-287 (151 \pm 60 ; 15) long, 100-257 (188 $\pm 44 ; 15)$ wide, wall thickness $2.5-22(10 \pm$ 8; 8) (Figs 4a and 8a).

Male. Four testes rounded to oblique (Figs 3a and 8d); deferent vessels unite in large, pyriform seminal vesicle 70-245 (146 \pm 42$)$ long, 52-125 (85 \pm 23$)$ wide, wall thickness $2.5-7.5$ (4 $\pm 2 ; 20)$ (Figs $4 \mathrm{~b}$ and $8 \mathrm{a})$; prostatic bulb short, $145-400(255 \pm 64)$ long, 57-192 (120 \pm 33 ) wide, wall thickness $2.5-20(11 \pm 5$; 19) (Figs $4 \mathrm{~b}$ and $8 \mathrm{a})$; cirrus long and slightly curve 195-212 (202 $\pm 9 ; 3)$ long (Figs 3b, 4b, 7 and 8a); shaft 165-185 (174 $\pm 10 ; 3)$ long, with maximum width at base 65-72 (68 $\pm 4 ; 3)$; introvert $25-30(27 \pm 2 ; 3)$ long, with width at base $15(n=3)$, with maximum width 15-17 $(17 \pm 1,3)$ at level of swelling. Introvert's swelling with approximately 27 rows of spines, and 9 short and thick spines in each row (Figs $3 \mathrm{~b}$ and 7). Ratio of total body length (without tentacles):/total length of cirrus 14.2: 1; ratio of total length of cirrus/maximum width of shaft at its base $3: 1$; ratio of total length of cirrus/total length of introvert 7.5: 1 .

Taxonomic summary.

Type host. Aegla grisella Bond-Buckup \& Buckup, 1994 (Crustacea, Anomura).

Other host. Aegla spinipalma Bond-Buckup \& Buckup, 1994 (Crustacea, Anomura).
Type locality. Tributary creek of the Forqueta river, Perau de Janeiro, Arvorezinha, Rio Grande do Sul, Brazil (28 51'9.85"S; $52^{\circ} 17$ '55.02'W).

Other locality. Tributary creek of the Fão river $\left(29^{\circ} 12^{\prime} 2.81^{\prime \prime} \mathrm{S}\right.$; $\left.52^{\circ} 11^{\prime} 31.80^{\prime \prime} \mathrm{W}\right)$, Pouso Novo, Rio Grande do Sul, Brazil (29¹2’2.81’'S; $52^{\circ} 11$ '31.80’'W).

Site. Branchial chambers and body surface; eggs cemented on external surfaces of exoskeleton (Figs 2b-2d).

Prevalence. 92.4\%.

Average intensity of infestation. 14.8

Helminth specimens deposited. 'Coleção Helmintológica do Instituto Oswaldo Cruz’: CHIOC 38212 (HOLOTYPE); CHIOC 38213 (cirrus). 'Coleção de Invertebrados do Instituto Nacional de Pesquisas da Amazônia': INPA 663 (paratype); INPA 664 (cirrus). 'Colección de Invertebrados, División Zoología Invertebrados, Museo de La Plata': MLP-He 7100 (paratype); MLP-He 7101 (cirrus).

Host specimens deposited: 'Coleção de Crustáceos, Departamento de Zoologia, UFRGS': 6119 - 6142 (A. grisella); 'Coleção Zoológica, Museu de Ciências Naturais da Univates (MCN/UNIVATES)': ZAUMCN 1072-1076 (A. grisella).

Etymology. The specific epithet grisella refers to the type host and act as a reminder of the importance of its preservation.

Remarks. The EPs of the species hosted by crustaceans usually present a great variation in shape, however T. grisella sp. nov. presents an EPs' shape similar to Temnocephala pignalberiae Dioni, 1967 (Seixas et al. 2015b). In the male reproductive system, the seminal vesicle has a thin muscular wall ( $4 \mu \mathrm{m}$ thick on average), in contrast with a strong 


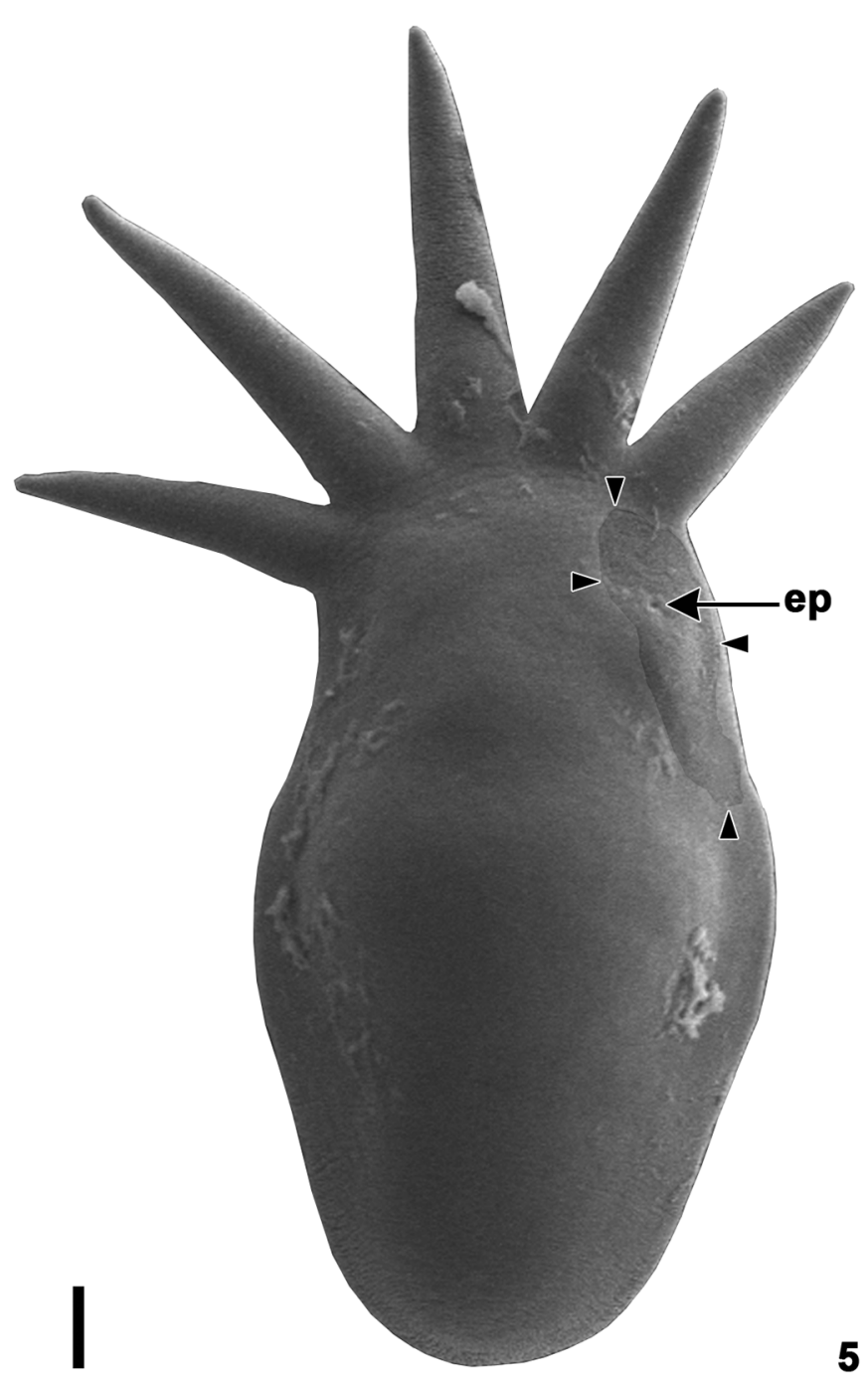

Figure 5. Scanning Electron Microscopy of Temnocephala grisella sp. nov. showing the highlighted epidermal 'excretory' syncytial plate; excretory pore (ep) and limits of the plate (head arrows). Scale bar $=100 \mu \mathrm{m}$.

muscular wall of the prostatic bulb (11 $\mu \mathrm{m}$ thick on average). The cirrus showed intraspecific variation of the curvature from straight to slightly curve. The introvert portion of the cirrus has a small variation in length $(25-30 \mu \mathrm{m})$ but the same measure in width at base $(15 \mu \mathrm{m})$ in all specimens measured. The total length of the cirrus is three times bigger than the maximum width of the shaft at its base. The posterior pair of the testes is two times bigger than the anterior pair.

\section{Discussion}

Temnocephala chilensis, T. axenos, T. talicei and T. mertoni present cirrus measuring, on average, between 123-149 $\mu \mathrm{m}$ long (Damborenea \& Cannon 2001, Volonterio 2007), while T. cyanoglandula has the largest cirrus among anomuran crabs temnocephalans, having an average length of $256 \mu \mathrm{m}$ (Amato et al. 2003). Among these species, T. grisella sp. nov. has a cirrus of intermediate size, measuring $179 \mu \mathrm{m}$

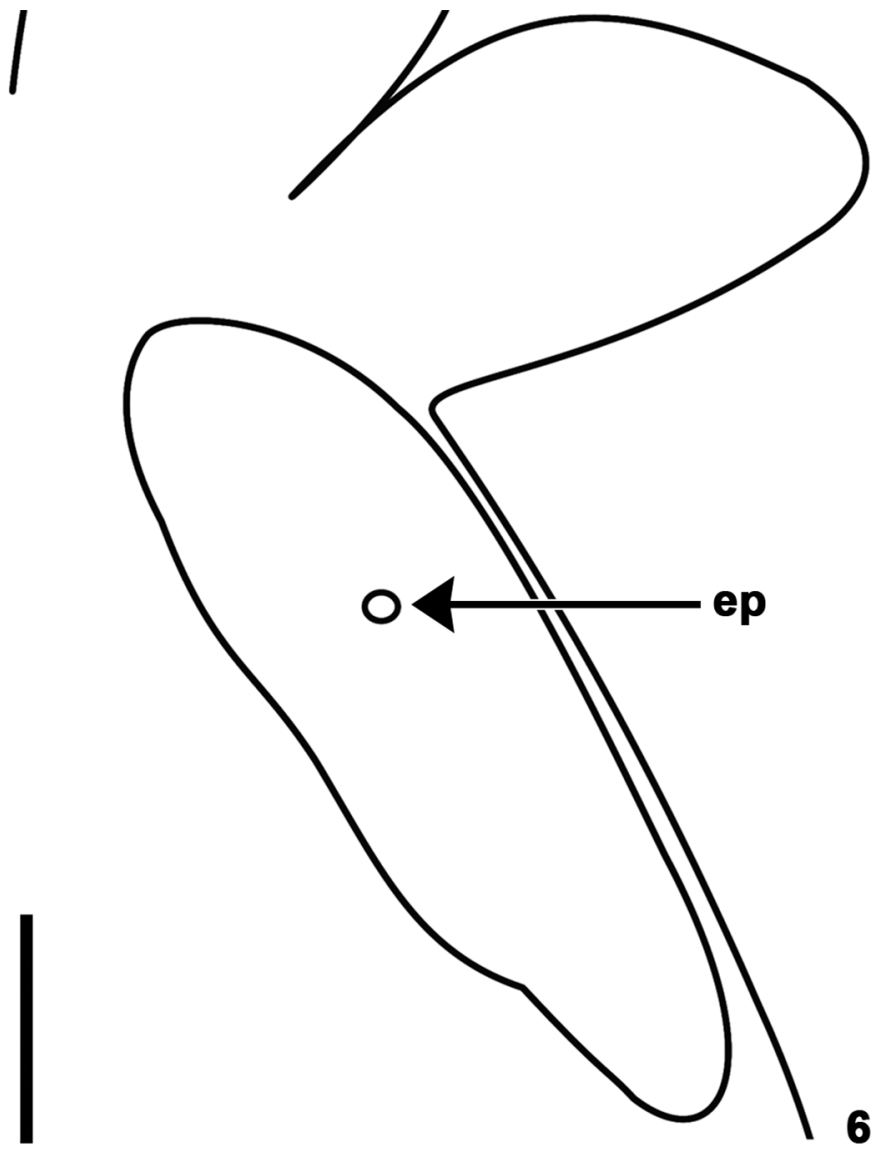

Figure 6. Diagram of the epidermal 'excretory' syncytial plate of Temnocephala grisella sp. nov., showing the limit of the plate and the excretory pore (ep). Scale bar $=100 \mu \mathrm{m}$.

on average (Table 1). Dioni (1967c) studied specimens of T. axenos ectosymbiont on species of Aegla and Parastacus Huxley, 1879 from Uruguay and Brazil, finding a great cirrus' size variability (125-150 $\mu \mathrm{m})$, although, due to the lack of data on female reproductive system, is impossible to compare with the new species described in the present work. Nonetheless, both cirri measurements presented by Dioni (1967c) and Volonterio (2007), on their description of Uruguayan specimens of T. axenos, differ from that of T. grisella sp. nov. (Table 1).

Lamothe-Argumedo (1968) also found a great cirrus' size variability (144-206 $\mu \mathrm{m}$ ) while re-describing T. mexicana. Although the range was similar to T. grisella sp. nov., the shape of the cirrus differed. In fact, the cirrus' shape of T. mexicana presented by the author differs greatly from the original description of the species. Vayssière (1898) describe the cirrus as a little curved, with an "exsertile" portion at its outer end, meaning that it have a portion projected beyond the organ, which is visible in the diagram provided by the author. The cirrus described by Lamothe-Argumedo (1968) doesn't have this characteristic introvert and was similar to T. mertoni by having a slightly sinuous portion in the shaft. The single vaginal sphincter of T. mexicana, evidenced by the diagram presented, is also similar to T. mertoni. These cirrus and vaginal sphincter characteristics differs $T$. mexicana and $T$. mertoni from $T$. grisella sp nov. 


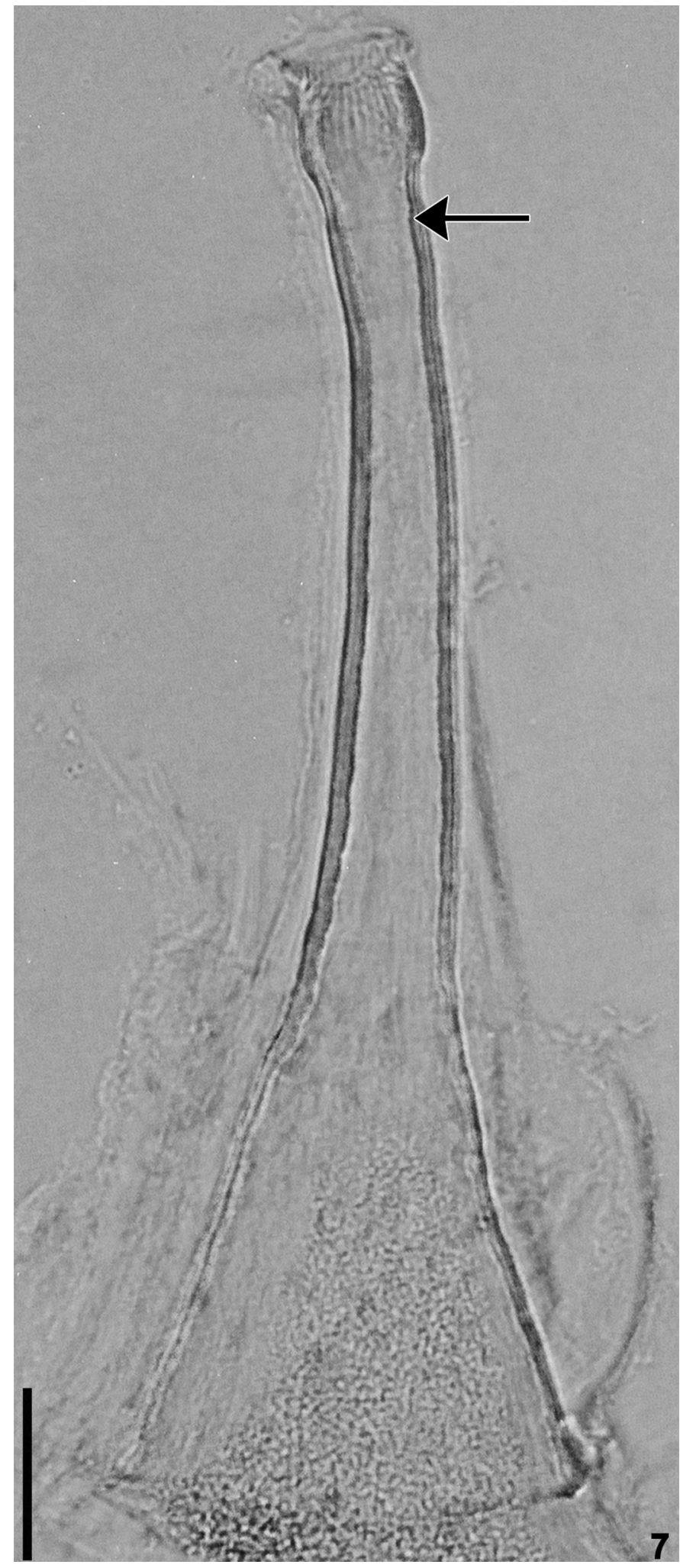

Figure 7. Cirrus of Temnocephala grisella sp. nov., showing the limit of introvert-shaft (arrow). Scale bar $=25 \mu \mathrm{m}$.
Damborenea \& Cannon (2001), on a neotropical temnocephalans revision, pointed out the absence of any muscular structure (sphincter) in $T$. chilensis vagina. They also recorded a conic cirrus with a swollen introvert measuring an average of $149 \mu \mathrm{m}$ in length. All these characteristics differs from $T$. grisella sp nov. The authors also assert the lack of sphincter on T. talicei. Volonterio (2009), while re-describing $T$. talicei, has shown the existence of a single conspicuous and asymmetric distal sphincter, pointing out similarities of this species with T. mertoni. Likewise T. talicei and T. mertoni, T. cyanoglandula also have only one vaginal sphincter, which is also distal and asymmetric (Seixas et al. 2015a).

Temnocephala dionii have a unique cirrus with a "groove between introvert and the shaft" and a single vaginal sphincter (Ponce de León et al. 2015), which differentiates $T$. dionii from the new species. This cirrus' shape characteristics have some similarities with the original description of $T$. mexicana' cirrus, pointing out the importance of a future revision of T. mexicana.

Temnocephala axenos, alike $T$. grisella sp. nov., has two vaginal sphincters, one proximal asymmetric and a symmetric distal, but they greatly differ on size. In the re-description made by Volonterio (2007), T. axenos presented both vaginal sphincters with similar average sizes (43 $\mu \mathrm{m}$ proximal e $45.5 \mu \mathrm{m}$ distal), whereas $T$. grisella sp. nov. presents one proximal large vaginal sphincter ( $83 \mu \mathrm{m}$ on average) and a smaller distal one $(56.5 \mu \mathrm{m}$ on average). The author also pointed out that both sphincters of $T$. axenos are located at the final portion (distal) of the vagina, very close to one another. In contrast, in T. grisella sp. nov., the vaginal portion between the proximal and distal sphincters is quite long with a strong muscular wall (Fig. $4 \mathrm{a}$ - aps), measuring $38 \mu \mathrm{m}$ in length on average. Therefore, in $T$. grisella sp. nov., the proximal sphincter is located in the middle of the vagina, while the distal one is at the tip end of the organ. The total vaginal length of $T$. grisella $\mathbf{s p . ~ n o v . ~ i s ~ l a r g e r ~}$ than $T$. axenos, and both species have a vesicula intermedia, rather than seminal receptacles, that it is also slightly larger in specimens of $T$. grisella sp. nov. (Table 1).

Volonterio (2007) described T. axenos' EPs like “elliptical excretory syncytia, small, extends from base of external tentacles to level of anterior portion of intestine", however she did not provide character measurements. Temnocephala grisella sp. nov. has elongate EPs, wider in the area surrounding the excretor pore. The excretory pore is central and in the anterior portion of the plates. Temnocephala grisella sp. nov.' EP is the larger in total length (397.5 $\mu \mathrm{m}$ on average) among epibionts temnocephalans on crustaceans already registered, T. cyanoglandula's being the second largest, with a total length of $284.4 \mu \mathrm{m}$ on average (Seixas et al. 2015b). The larger than wide EPs of T. grisella sp. nov. are evidenced with the ratio of total length of the EPs/total body length. Six EPs, approximately, could occupy the total length of the body while in the wider than long EPs' species, such as Temnocephala trapeziformis Amato, Amato \& Seixas, 2006 (Seixas et al. 2015b), 17 EPs are necessary to occupy the total length of the body. 

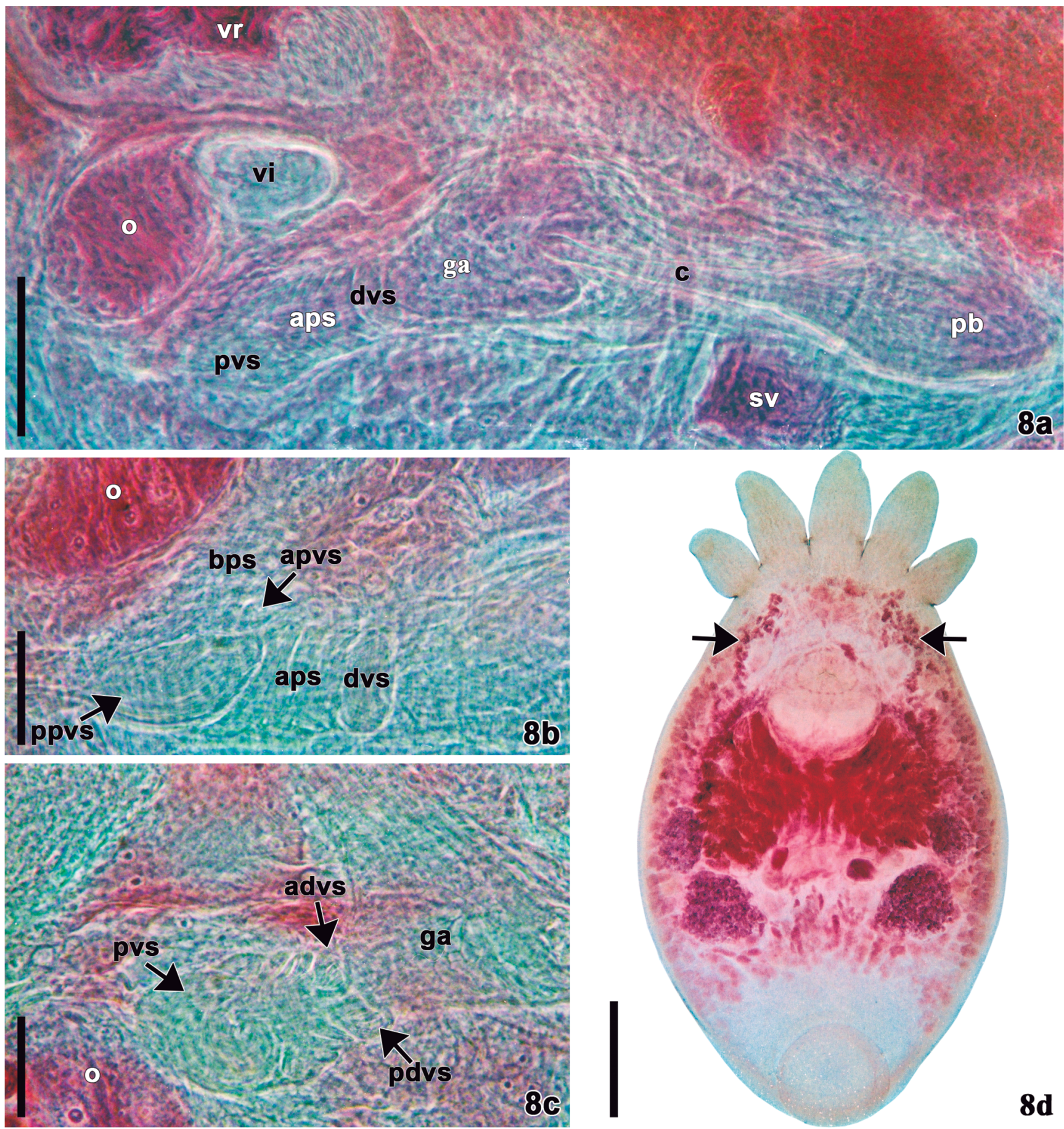

8d

Figure 8. Temnocephala grisella sp. nov. (8a) Reproductive system, showing: after proximal sphincter - vagina (aps), cirrus (c), distal vaginal sphincter (dvs), genital atrium (ga), ovary (o), prostatic bulb (pb), proximal vaginal sphincter (pvs), seminal vesicle (sv), vesicula intermedia (vi), and vesicula resorbens (vr). Scale bar $=100 \mu \mathrm{m}$. (8b-8c) Partial female reproductive system. (8b) after proximal sphincter of the vagina (aps), anterior portion of the proximal vaginal sphincter (apvs), before proximal sphincter of the vagina (bps), distal vaginal sphincter (dvs), ovary (o), and posterior portion of the proximal vaginal sphincter (ppvs). Scale bars $=50 \mu \mathrm{m}$. (8c) anterior portion of the distal vaginal sphincter (advs), genital atrium (ga), ovary (o), posterior portion of the distal vaginal sphincter (pdvs), and proximal vaginal sphincter (pvs). Scale bars $=50 \mu \mathrm{m}$. (8d) Adult specimen, showing the cyanophilous glands (arrows). Scale bar $=500 \mu \mathrm{m}$. 
Seixas, S.A. et al.

Table 1. Morphometric data from Temnocephala grisella (present work) comparing with Temnocephala mertoni and Temnocephala axenos (Volonterio 2007). Measurements are in micrometers $(\mu \mathrm{m})$, unless otherwise indicated.

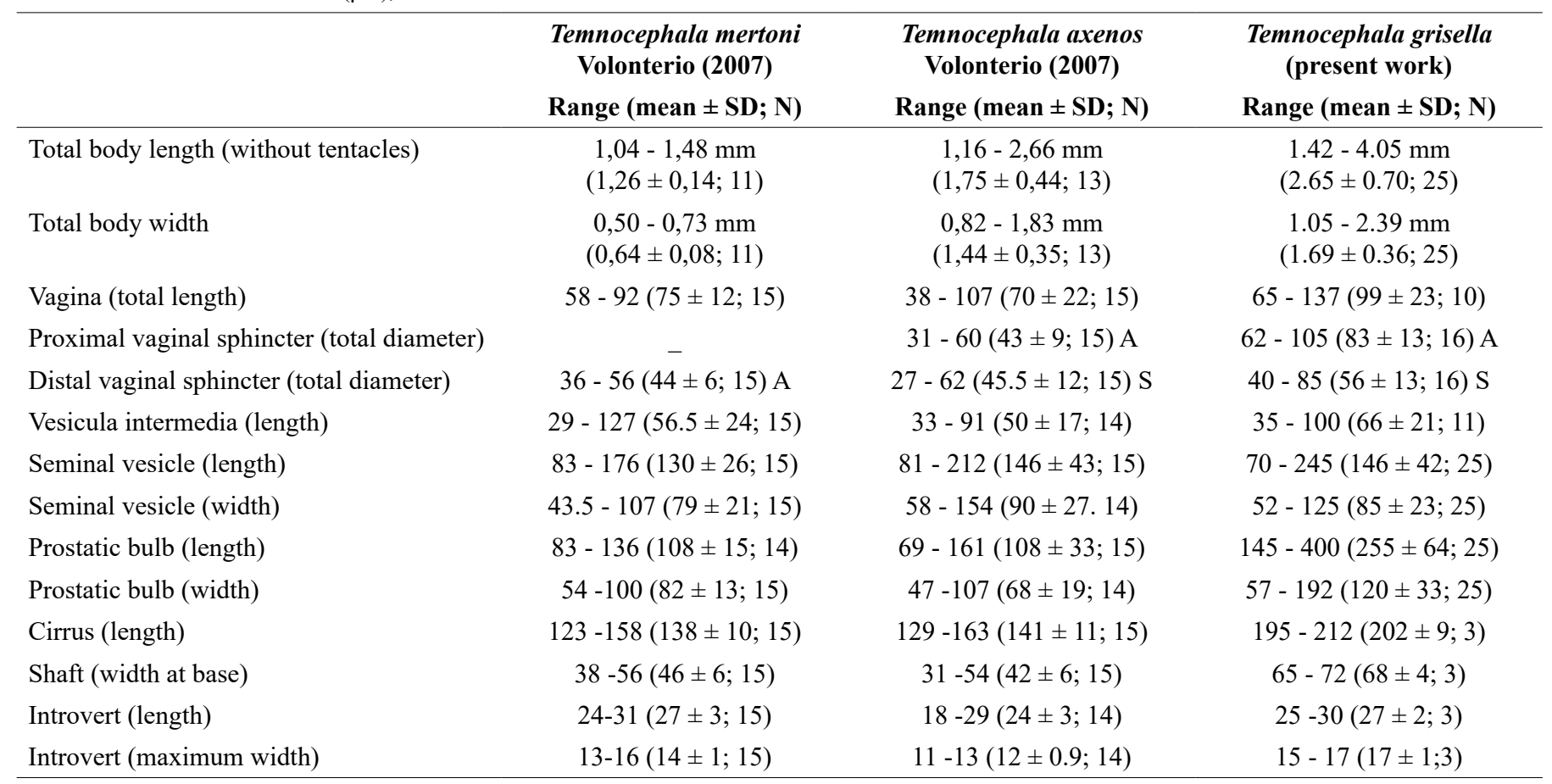

$\mathrm{SD}=$ Standard deviation; $\mathrm{N}=$ number of specimens measured for a given character; $\mathrm{A}=$ asymmetric; $\mathrm{S}=$ symmetric.

Temnocephala mertoni' EPs have a similar shape to the new species described in the present work, however their measurements, as well as T. axenos, have not been provided. Observing the illustrations of the species description, T. mertoni' EPs extend from the limit of the tentacles up to the intestine (Volonterio 2007), while in T. grisella sp. nov., the EPs start before the limit of the tentacles and extend until almost the half of the intestine, suggesting a larger overall size.

Amato et al. (2003) distinguished T. cyanoglandula by the unique appearance of its cyanophilous glands, which form "two irregular-shaped, grape-like bunches of cells, located in the anterior portion of the body, at the level of mouth and pharynx". The same structures are visible in $T$. grisella sp. nov. (Figs 3a and 8d), but, even utilizing the same staining methods, they do not appear to be as conspicuous nor its ducts visible, as they are in T. cyanoglandula. According Volonterio (2007), T. axenos has four paranephrocytes and T. mertoni, one pair. Similar to T. mertoni, T. grisella sp. nov. also have one pair of large, round, more central paranephrocytes (Fig. 3a - head arrows).

The host $A$. grisella was included in the list of endangered species of the State of Rio Grande do Sul in the category of vulnerable, according to IUCN (The World Conservation Union) criteria (Marques et al., 2002). In addition, the sampling point at the municipality of Arvorezinha, although well preserved, has recently been threatened by the construction of a hydroelectric power plant. The 'Perau de Janeiro' is home to some records of highly restricted and endemic species, such as the amphibian Melanophryniscus admirabilis Di Bernardo, Maneyro \& Grillo, 2006, a critically endangered species (Fonte et al. 2014). Due to these threats, the records of associated fauna of these crustaceans at this locality becomes even more necessary and can aid in the conservation policy of aeglids and its epibionts, as well as the environment that has undergone a series of actions that threaten the original biodiversity of the region. The accelerated process of degradation becomes even more worrying in a region where a great part of the fauna is still unknown, thus, it is essential to carry out taxonomic, ecological and environmental studies whose results make the elaboration of conservation actions possible.

\section{Acknowledgments}

To PNPD/CAPES for the Post-Doctoral Scholarship awarded to $\mathrm{SAS}$; to Dr. Georgina Bond-Buckup (UFRGS) for identifying the species of Aegla; to Dr. Suzana B. Amato (UFRGS) for the permission to use the Zeiss Axiolab microscope to take the photomicrographs; to the staff of the Laboratorio MEV at Tecnovates, Univates for the SEM operation; to the biologists Camila A. Schmidt, Guilherme Consatti, Tairis Costa, and Gerson Luiz Ely Junior for their invaluable help in the field and in the laboratory; to the environmental engineer Daniel Martins dos Santos for the help on the field and with the design of the maps; and to the biologists and english translators Joyce Baptista and John O'Donnell for kindly reviewing the English of the several versions of the manuscript.

\section{Author contributions}

Samantha Alves Seixas - Substantial contribution in the concept and design of the study; Contribution to data collection; Contribution to data analysis and interpretation; Contribution to manuscript preparation; Contribution to critical revision, adding intelectual content.

Norton Dametto - Contribution to data collection; Contribution to data analysis and interpretation; Contribution to manuscript preparation;

Eduardo Périco - Contribution to manuscript preparation; Contribution to critical revision, adding intelectual content. 


\section{Conflicts of interest}

The authors declare that they have no conflict of interest related to the publication of this manuscript.

\section{References}

AMATO, J.F.R., AMATO, S.B. \& DAUDT, L.C.C. 2003. New species of Temnocephala Blanchard (Platyhelminthes, Temnocephalida) ectosymbiont on Aegla serrana Buckup \& Rossi (Crustacea, Anomura) from southern Brazil. Rev. Bras. Zool. 20(3): 493-500.

AMATO, J.F.R., SEIXAS, S.A. \& AMATO, S.B. 2007. A new species of Temnocephala Blanchard (Platyhelminthes, Temnocephalida) ectosymbiont on creeping water bugs, Cryphocricos granulosus De Carlo (Hemiptera, Naucoridae) from southern Brazil. Rev. Bras. Zool. 24(4): 1043-1051.

BAER, J.G. 1931. Étude monographique du groupe des Temnocephales. Bull. biol. Fr. Belg. 1: 1-57.

BUSH, A.O., LAFERTY, K.D., LOTZ, J.M. \& SHOSTAK, A.W. 1997. Parasitology meets ecology on its own terms: Margolis et al., revisited. J. Parasitol. 83: 575-583.

DAMBORENEA, M.C. 1992. Especies de Temnocephala (Platyhelminthes, Temnocephalidae) de crustaceos y moluscos de la Argentina. Iheringia ser. zool. 72: 3-21.

DAMBORENEA, M.C., CÉSAR, I.I. \& ARMENDÁRIZ, L.C. 1997. Especies de Temnocephala (Platyhelminthes, Temnocephalidae) de la Isla Martín García, Buenos Aires, Argentina. Neotropica 43(109-110): 123-124.

DAMBORENEA, M.C. \& CANNON, L.R.G. 2001. On neotropical Temnocephala (Platyhelminthes). J. Nat. Hist. 35: 1103-1118.

DIONI, W. 1967a. Temnocephalas argentinas. I. Notas sobre Temnocephala chilensis (Moquin-tandon, 1846) (Platyhelmintha). Physis 26(73): 405-410.

DIONI, W. 1967b. Temnocephalas argentinas. II. Las temnocephala de Aegla del Museo Argentino de Ciencias naturales "Bernardino Rivadavia" (Platyhelmintha). Physis 26(73): 509-514.

DIONI, W. 1967c. Temnocephalas uruguayas II. Descripción de Temnocephala talicei n. sp. y notas sobre T. axenos Monticelli (Platyhelmintha). Physis 26(73): 477-484.

DIONI, W. 1968. Presencia de Temnocephala talicei (Platyhelmintha, Temnocephalidae) en Paraguay. Physis 27(75): 263-264.

DIONI, W. 1972. Didymorchis, Temnocephala (Platyhelminthes) y Stratiodrilus (Annelida) vermes epizoicos sobre Aegla y Parastacus (Crustacea, Decapoda) de Lagos Andino-Patagonicos. Notas taxinomicas y biogeográficas. Acta Zoo Lilloana. XXIX: 167-179.
FONTE, L.F., ABADIE, M., MENDES, T., ZANK, C. \& BORGES-MARTINS, M. 2014. The times they are a-changing: How a multi- institutional effort stopped the construction of a hydroelectric power plant that threatened a critically endangered red-belly toad in Southern Brazil. FrogLog 112: 18-21.

KASHI, A. M., TAHERMANESH, K, CHAICHIAN, S., JOGHATAEI, M.T., MORADI, F., TAVANGAR, S.M., NAJAFABADI, A.S.M., LOTFIBAKHSHAIESH, N., BEYRANVAND, S.P., ANVARI-YAZDI, A.F. \& ABED, S.M. 2014. How to prepare biological samples and live tissues for Scanning Electron Microscopy (SEM). GMJ 3(2):63-80.

LAMOTHE-ARGUMEDO, R. 1968. Redescripción de Temnocephala mexicana Vayssiere, 1898, ectocomensal de crustáceos mexicanos. An. Inst. Biol. Univ. Nal. Autón. México. 39(1): 1-12.

MARQUES, A.A.B., FONTANA, C.S., VÉLEZ, E., BENCKE, G.A., SCHNEIDER, M. \& REIS, R.E. 2002. Lista de Referência da Fauna Ameaçada de Extinção no Rio Grande do Sul. Decreto no 41.672, de 11 junho de 2002. FZB/MCT-PUCRS/PANGEA, Porto Alegre.

MONTICELLI, F.S. 1898. Sulla Temnocephala brevicornis Montc. (1889) e sulle temnocefale in generale. Boll. Soc. Nat. Napoli 12: 72-127.

PONCE DE LEÓN, R., BERÓN VERA, B. \& VOLONTERIO, O. 2015. Description of a New Temnocephala Species (Platyhelminthes) from the Southern Neotropical Region. J. Parasitol. 101(4): 424-428.

SEIXAS, S.A., AMATO, J.F.R. \& AMATO, S.B. 2010. Redescription of Temnocephala iheringi (Platyhelminthes: Temnocephalida) based on specimens from Pomacea canaliculata (Mollusca: Ampullariidae) of the State of Rio Grande do Sul: the possible type host and type locality. Zoologia 27(2): 245-257.

SEIXAS, S.A., AMATO, J.F.R. \& AMATO, S.B. 2015a. A complete description of the female reproductive system of Temnocephala cyanoglandula Amato, Amato \& Daudt (Platyhelminthes, Temnocephalida). Neotrop. Helminthol. 9(2): 371-376.

SEIXAS, S.A., AMATO, J.F.R. \& AMATO, S.B. 2015b. The epidermal 'excretory' syncytial plates in species of Temnocephala (Platyhelminthes, Temnocephalida): Proposal of a new methodology. R. Bras. Bioci. 13(4): 237-244.

VAYSSIÈRE, A. 1898. Description du Temnocephala mexicana, nov. sp. Ann. Fac. Sci. Marseille. 8: 227-235.

VOLONTERIO, O. 2007. A new species of Temnocephala (Platyhelminthes, Temnocephalida) and a description of $T$. axenos from Uruguay. J. Nat. Hist. 41(21-24): 1245-1257.

VOLONTERIO, O. 2009. Redescription and designation of a neotype of Temnocephala talicei Dioni, 1967 (Platyhelminthes: Temnocephalida). J. Parasitol. 95(2): 345-348. 